\title{
Investigation of Serum Brain Derived Neurotrophic Factor Levels in Children and Adolescents Aged 12 to 18 Years with Depressive Disorder
}

\author{
Erman Esnafoglu ${ }^{1}$, Yeşim Taneli ${ }^{2}$, Emine Kırhan $^{3}$, Melahat Dirican $^{3}$ \\ ${ }^{1}$ Department of Child and Adolescent Psychiatry, Faculty of Medicine, Ordu University, Ordu, Turkey \\ ${ }^{2}$ Department of Child and Adolescent Psychiatry, Faculty of Medicine, Uludag University, Bursa, Turkey \\ ${ }^{3}$ Department of Biochemistry, Faculty of Medicine, Uludag University, Bursa, Turkey
}

Received: 11 July 2018, Accepted 22 July 2018, Published online: 30 August 2018 (C) Ordu University Institute of Health Sciences, Turkey, 2018

\begin{abstract}
Objective: It has been suggested that the neuroplastic processis associated with the pathogenesis of psychiatric disorders including depressive disorder. It is thought that brain derived neurotrophic factor (BDNF) is an important factor in neuroplasticity in depressive disorder. BDNF is play an important role in survival of neurons, synaptic plasticity, formation of synaptic connections and neurodevelopment. Insulin like growth factor-1 (IGF-1) is found in various areas of the brain. IGF-1 is involved in brain growth, development and mylination, also in brain plasticity. IGF-1 affect the genesis of neurons, astrocytes, oligodendrocytes and endothelial cells. In this study we aimed to evaluate serum levels of BDNF and IGF1 , which is also accepted as a neurotrophic factor, in children and adolescents between 12-18 years with depressive disorder.

Methods: The patient group was composed of 35 subjects ( 26 females; 9 male), while the control group was composed of 22 subjects (14 females; 8 male). Sociodemographic form, Kovac's depression scale, and statetrait anxiety inventory were applied to all subjects. Serum BDNF and IGF-1 levels were measured with ELISA. Moreover complete blood count, biochemical tests, thyroid and sex hormones were tested.

Results: There was no significant difference between the patient group and the control group in terms of the BDNF and IGF-1 levels (respectively p values 0.547 and 0.968). When the groups divided into female and male subgroups, statistically significant differences were not found again. Moreover age, gender, menstrual states, suicide attempts, suicide thoughts, smoking and Body Mass Index had no effects on the BDNF. There was also no effects on IGF-1 levels, except age. There was negative correlation between age and IGF-1 in all subjects.

Conclusion: The results of this study do not support the association of depressive disorder with changes in serum BDNF and IGF-1 levels in children and adolescents. But larger prospective studies are needed to show better the effects of these factors.

Key words: Brain derived neurotrophic factor, insulin-like growth factor-1, depression, child and adolescent, neurotrophic factor
\end{abstract}

Address for correspondence/reprints:

Erman Esnafoğlu

Telephone number: +90 (533) 7724634

E-mail: ermanesnafoglu@yahoo.com.tr

DOI: $10.19127 / \mathrm{mbsjohs} .442649$ 


\section{Introduction}

Depressive disorder (DD) is a common disorder with a tendency to become chronic and recurring that causes physical and psychosocial disability (Kaufman et al., 2006). Depression in adolescents causes increased mortality due to suicidal and parasuicidal behavior in addition to drug abuse, negative life events, and weak academic and psychosocial functioning (Park and Googyer, 2000). The definite rates of DD among children and adolescents are not known. Epidemiological studies report the prevalence of depression in children is 2$4 \%$ and in adolescents is 5-8\% (Birmaher and Brent, 1998; Park and Googyer 2000; Kaufman et al., 2006). The gene-environment interaction is found in the etiology of DD; however, the characteristics of this interaction and the degree of effect of the environment is not known (Herken, 2002).

Recent studies have shown that some structural changes occur in regions of the brain related to mood in patients with depression with a reduction in glial cells and neurons. The brain, contrary to what was previously believed, has high plasticity capacity with processes like growth and branching of dendrites and restructuring of synapses understood to continue after the childhood period. Currently, as a result of this data, the opinion that disrupted or insufficient neuroplasticity plays a role in the formation of depression and that depression may be caused by insufficient neuroplasticity of brain structures effective on mood formation has gained importance (Uzbay, 2005).

Changes in the expression of brain-derived neurotrophic factor (BDNF), with duties in neuroplasticity processes and accepted as a neurotrophic factor, have been reported to cause many psychiatric disorders including depression and schizophrenia (Tapia-Arancibia et al., 2004). Low BDNF levels play a role in the pathophysiology of DD and associated disorders and many studies have shown the amount of BDNF increases with antidepressant use (Aydemir et al., 2005). BDNF polymorphism forms a potential risk for depression within the framework of gene-gene-environment interaction in children (Kalueff et al., 2007). It is known BDNF can pass the blood-brain barrier (Hashimoto et al., 2004). The basic source of BDNF in serum is the brain (Katoh-Semba et al., 2007).

Insulin-like growth factor (IGF-1) is a polypeptide hormone with increasing effect on growth in the central nervous system. Basically IGF1 is synthesized in the liver and though it passes into circulation from there, IGF-1 is also produced by the central nervous system including the hippocampus (McCusker et al., 2006). Peripherally-synthesized IGF-1 passes the blood-brain barrier and thus, IGF1 in both circulation and in the central nervous system affects neuronal functions in the hippocampus (Schimidt and Duman, 2007). Additionally, it was identified that IGF-1 expression increased in the hippocampus with chronic antidepressant treatment (Hoshaw et al., 2005). In animal studies, the antidepressant effect of IGF-1 was shown. Finally, IGF-1 may play a role in pathophysiology and treatment of DD like neurotrophic factors like BDNF. With these characteristics, IGF-1 may be assessed as a neurotrophin. In the hippocampus, IGF-1 works synergistically with BDNF and they each increase the effects of the other (McCusker et al., 2006).

In this study, we identified and compared the BDNF and IGF-1 levels in serum of children and adolescents aged from 12-18 years with and without DD to research their possible roles in DD etiology.

\section{Methods}

Subjects

Subjects were selected from individuals monitored as inpatients or attending as outpatients at Uludağ University Faculty of Medicine Pediatric Mental Health and Diseases Clinic. These included a 35 -subject ( 26 females, 9 male) patient group with "major depressive disorder" diagnosis (DSMIV/ICD-10) and a 22 -subject (14 females, 8 male) control group with no psychiatric or other medical disease diagnosis. As the DSM V had not been released at the time of the study, DSM-IV was used for valid criteria. When creating the groups, those with any psychiatric diagnosis accompanying DD apart from generalized anxiety disorder, those with any active chronic systemic or neurological disease, those taking any psychiatric medication in the previous 3 weeks and those with drug and alcohol abuse or addiction were excluded from the study. Subjects who agreed to participate in the study were informed, along with their parents, about the research and informed and written consent was obtained. The study was permitted by Uludağ University Faculty of Medicine ethics committee.

\section{Forms and Scales administered Sociodemographic Information}

The sociodemographic information form developed in the study was used to collect 
demographic information about the volunteers along with points obtained from the scales; height, weight and body mass index; gender, number of siblings, graduation degree, who they live with, whether they live with their original family; maternal and paternal educational levels, monthly income of the family; whether they smoke, if so how many per day; whether they have attempted suicide to date; and for female subjects whether they are menstruating, if so the age of initial menstruation and the current day of their cycle.

Children's Depression Inventory (CDI) (App 4)

This scale is the most commonly used among self-assessment scales for childhood depression and psychometric properties have been most researched. It was prepared by M. Kovacs based on the opinion that "childhood depression exists, can be observed and measured and has similar characteristics to that in adults". The validity and reliability studies in Turkey were completed by Oy in 1991 on 6-17 year olds (Oy, 1991). The children's depression inventory may be applied to children aged 6 to 17 years. It takes about 30 minutes to fill in the inventory which comprises a total of 27 items. Cut-off points were determined as 19.

State-Trait Anxiety Inventory (STAI-I, STAI-II)

This was developed in 1970 by C.D. Spielberger. The validity and reliability study for Turkey was completed by Öner and Le Compte in 1985 (Öner 1985). There are two separate subscales containing 20 items each included within the scale. The state anxiety inventory determines how individuals feel at a certain moment and under certain conditions. Answers are chosen according to the degree of agreement with the feeling, thought or behavior stated in the idem as "not at all", "somewhat", "moderately so" and "very much so". The trait anxiety inventory determines how the individual feels independent of the situation and conditions they find themselves in. Answers are chosen according to degree of frequency as "almost never", "sometimes", "often" and "almost always". The total points obtained from both scales varied from 20 to 80 points. Higher points indicate higher levels of anxiety. The cut-off point for both subscales is 45 .

\section{Collection and Storage of Samples}

Blood samples were taken from all cases after overnight fasting. Blood taken for routine tests was studied the same day. Blood samples were taken in a dry tube (Vacutainer, England) with the aid of a 0.18 x $40 \mathrm{~mm}$ needle from the veins in the forearm antecubital region. Samples were centrifuged for 5 minutes at $3000 \mathrm{rpm}$ and the serum was aspirated. Serum separated in the study was stored at $-80 \mathrm{C}$ until analysis.

\section{BDNF and IGF-1 Measurement}

Serum BDNF levels were measured using a solid-phase sandwich two-way enzyme-linked immunoassay (ELISA) BDNF (human) ELISA kit (Phoenix Pharmaceuticals Inc. California, USA). Serum IGF-1 levels were measured using a chemiluminescence immunoassay method with its own kit on an Immulite 2000 device (Siemens, UK). The tests were used in accordance with instructions.

\section{Statistical Analysis}

In our study, SPSS for Windows 16.0 (Chicago, IL) program was used for analyses. Variables with continuous values are given as mean, standard deviation, maximum and minimum values. Variables with continuous values were tested for normality with the Shapiro-Wilk test. Comparison of two groups of independent variables with normal distribution used the independent samples $t$ test. Two groups of independent variables without normal distribution (nonparametric) were compared with the Mann-Whitney U test. Comparison of groups with variables with categoric values used the chi-square test. The Spearman test was applied for correlation calculations of nonparametric variables and categoric variables. The Pearson test was applied to variables showing normal distribution. In our study the level of significance was accepted as $p<0.05$. Taking note of the rapid development of children and adolescents, age was calculated in months and shown as years and months.

\section{Results}

There were no statistically significant differences identified between the groups in terms of gender and body mass index values ( $\mathrm{p}$ values 0.392 and 0.676 , respectively). There was a statistically significant difference identified between the patient and control groups in terms of age $(\mathrm{p}=0.007)$; accordingly, the mean age of the patient group was higher compared to the control group (Table 1). The values obtained by the groups for the Kovacs depression inventory, state anxiety (STAI-1) and trait anxiety (STAI-2) are shown in Table 1. There were significant differences between the groups for these three parameters 
$(\mathrm{p}<0.001)$, with the patient group identified to have higher mean depression, state and trait anxiety points. The BDNF and IGF-1 values for the groups are shown in Table 1 . There was no significance found between the two groups (p values 0.547, 0.646 and 0.968 , respectively). When the groups are divided into subgroups according to gender, comparison of BDNF and IGF-1 values did not obtain significant results. Correlation analyses did not find any significant correlation. There was only a negative correlation between age and IGF-1 levels for all subjects $(\mathrm{p}=0.028 ; \mathrm{r}:-0.291$ ).

Table 1. Characteristics of the groups and measured BDNF and IGF-1 values

\begin{tabular}{|c|c|c|c|}
\hline & $\begin{array}{l}\text { Control } \\
\text { group } \\
(\mathbf{n}=35)\end{array}$ & $\begin{array}{l}\text { Patient } \\
\text { group } \\
(\mathrm{n}=22)\end{array}$ & $\begin{array}{l}\mathbf{P} \\
\text { values }\end{array}$ \\
\hline $\begin{array}{l}\text { Gender } \\
\text { (Female/Male) }\end{array}$ & $26 / 9$ & $14 / 8$ & $0.392^{\mathrm{a}}$ \\
\hline $\begin{array}{l}\text { Age (mean- } \\
\text { months } \\
\text { (year;months)) }\end{array}$ & $\begin{array}{l}179.8 \text { months } \\
\text { (14 years } 11.8 \\
\text { months) }\end{array}$ & $\begin{array}{l}189.4 \text { months } \\
\text { (15 years } 3 \\
\text { months) }\end{array}$ & $0.007^{\mathrm{b}}$ \\
\hline BMI $($ mean \pm SD $)$ & $20.89 \pm 4.3$ & $20.96 \pm 4.06$ & $0.676^{\mathrm{b}}$ \\
\hline $\begin{array}{l}\text { KDI points } \\
(\text { mean } \pm \text { SD) }\end{array}$ & $7.86 \pm 3.71$ & $27.94 \pm 5.65$ & $<0.001^{\mathrm{b}}$ \\
\hline $\begin{array}{l}\text { STAI-1 points } \\
\text { (mean } \pm \text { SD) }\end{array}$ & $34.5 \pm 9.04$ & $49.11 \pm 11.56$ & $<0.001^{\mathrm{b}}$ \\
\hline $\begin{array}{l}\text { STAI-2 points } \\
(\text { mean } \pm \text { SD) }\end{array}$ & $40.68 \pm 8.59$ & $52.38 \pm 12.58$ & $<0.001^{\mathrm{b}}$ \\
\hline $\begin{array}{l}\text { BDNF levels } \\
\text { (ng/ml) } \\
\text { Median (Min- } \\
\text { max) }\end{array}$ & $\begin{array}{l}2.45(0.62- \\
3.79)\end{array}$ & $2.39(0.4-3.75)$ & $0.547^{\mathrm{c}}$ \\
\hline $\begin{array}{l}\text { IGF-1 levels } \\
\text { (ng/ml) } \\
\text { Median (Min- } \\
\text { max) }\end{array}$ & $\begin{array}{l}320.55(164- \\
479)\end{array}$ & $\begin{array}{l}319.63(115- \\
502)\end{array}$ & $0.968^{c}$ \\
\hline
\end{tabular}

Note: achi-square test; b Student t test; c Mann WhitneyU test

BMI: Body mass index; KDI: Kovac's Depression Inventory; STAI-1: State anxiety inventory; STAI-2: Trait anxiety inventory

\section{Discussion}

This study is the first to assess BDNF and IGF-1 in children and adolescents with DD. Accordingly there were no clear changes identified in the patient group in terms of BDNF and IGF-1 values. These results contradict many studies showing low BDNF values in adult DD (Aydemir et al., 2005; Aydemir et al., 2007; Lee et al., 2007). Additionally, there are studies showing BDNF levels do not change in DD (Başterzi et al. 2009). In terms of IGF-1, this contradicts one study showing increased IGF-1 levels in DD (Franz et al., 1999). Considering the roles of BDNF and IGF-1 in neuroplasticity processes, they may be considered to be included in
DD pathogenesis (Uzbay 2005). After stress, it is proposed there are disruptions to the neuroplasticity processes in the brain, especially in the hippocampus (Duman et al. 2000; Duman 2002). BDNF in addition to affecting viability, development and differentiation of neurons, also affects learning and memory. In the adult brain, neurotrophic factors like BDNF have an increasing effect in viability of damaged neurons. During development, the survival of neurons is linked to the presence of targeted BDNF expression. In the absence of neurotrophic factors, neurons undergo programmed cell death; in other words, apoptosis (Wichers et al. 2008). In conclusion, when BDNF effects mentioned above are assessed in children and adolescents with DD, the lack of change in BDNF levels does not lead to the conclusion that BDNF does not have a role in DD pathogenesis. The results of the study should be confirmed with larger sample groups and considering other factors affecting BDNF.

In addition to its role in the CNS, IGF-1 plays a critical role in adult hippocampal neurogenesis. Systemic injection of IGF-1 increases neurogenesis in the hippocampus. Consistent with these results, blockage of peripheral IGF-1 reduces proliferation of neuronal progenitor cells in the hippocampus (Bhatia and Bhatia 2007). Generally, IGFs have properties like supporting capability for cellular proliferation, differentiation and metabolism/hypertrophy (nutrition transport, energy storage, gene transcription and protein synthesis) functions (O'Conner et al., 2008). Additionally, IGF-1 along with BDNF and serotonin regulate processes related to energy metabolism, stress response and aging in neurons (Mattson et al., 2004). A study of patients with depression (19 female patients and 16 healthy female controls aged 20-60 years) identified IGF-1 increased in DD (Duman et al., 2000). When all this data is assessed together, IGF-1 may have a role in DD pathogenesis. According to our study results, though there was no variation in IGF-1 levels which contradicts this data, there is a need for broad-scale studies about the possible role of IGF-1 in pediatric and adolescent DD pathogenesis together with assessment of other factors affecting IGF-1.

There are some limitations to this study. Firstly, increasing the sample number would ensure we reach more accurate conclusions. Also, in addition to peripheral assessment, it is necessary to perform measurements in cerebrospinal fluid to better reflect levels in brain tissue. The effects of other parameters 
that affect peripheral blood levels of these two neurotrophic factors like age, weight, nutritional intake, and a variety of drug use should be considered. Additionally, the cross-sectional nature of the study provides limited information about the effect of neurotrophic factors. Longer follow-up studies may allow thepossibility of obtaining more accurate results in this regard. Additionally, there was a statistically significant difference between the two groups in terms of age. This situation limits interpretations that can be made about the correlation of BDNF and IGF-1 with DD and other parameters. For more accurate evaluation, it is necessary to compare groups with similar characteristics like age and gender.

\section{Conclusion}

The basic finding of this study is that there were no significant differences in mean IGF-1 and BDNF levels between depressive patients and a control group aged 12-18 years. The lack of association between DD and changes in BDNF and IGF-1 levels should be confirmed by advanced studies of this topic.

Ethics Committee Approval: This study was approved by Uludağ University Faculty of Medicine Ethics Committee (No: 2008-4/26)

Peer-review: Externally peer-reviewed.

Author Contributions: Consept- E.E., Y.T.; Design-E.E., Y.T.; Supervision-E.E., Y.T.; Materials- E.E.; Data Collection/Data Process-E.E., Y.T.; Analyze or Comment- E.K., M.D.; Literature Scanning- E.E., Y.T., E.K.; Writer of Paper- E.E.; Critical Review- Y.T., E.K, M.D.

Conflict of Interest: No conflict of interest was declared by the author.

Financial Disclosure: The authors declared that This study was supported by Uludag University Scientific Research Project numbered T(U-2009.3).

\section{References}

Aydemir Ö, Deveci A, Taneli F. Theeffect of chronic antidepressant treatment on serum brain-derived neurotrophic factor levels in depressed patients: a preliminary study. Progr NeuroPsychopharmacol Biol Pschiatry, 2005; 29: 2615.
Aydemir Ö, Deveci A, Taskin OE, Taneli F, EsenDanac1 A. Serum Brain-derived neurotrophic factor level in dystimia: A comparative study with major depressive disorder. Prog NeuroPsychopharmacol Biol Pschiatry, 2007; 31: 1023-26.

Başterzi AD, Yazici K, Aslan E, Delialioğlu N, Taşdelen B, Acar ŞT et al. Effects of fluoxetine and venlafaxine on serum brain derived neurotrophic factor levels in depressed patients. Prog Neuro-Psychopharmacol Biol Psychiatry, 2009; 33: 281-285.

Bhatia SK, Bhatia SC. Childhood and adolescent depression. American Family Physician, 2007; 75: 73-80.

Birmaher B, Brent D. Practice parameters for the assessment and treatment of children and adolescent with depressive disorder. J Am Acad Child Adolesc Psychiatry, 1998; 37: 63-83.

Duman RS, Malberg J, Nakagawa S andD'Sa C. Neuronal plasticity and survival in mood disorders. Biol Psychiatry, 2000; 48: 732-39.

Duman RS. Pathophysiology of depression: the concept of synaptic plasticity. Eur Psychiatry, 2002; 17: 306-310.

Franz B, Buysse DJ, Cherry CR, Gray NS, Grochocinski VJ, Frank E et al. Insulin-like growth factor 1 and growth hormone binding protein in depression: a preliminary communication. J Psychiatr Res, 1999; 33: 1217.

Hashimoto K, Shimizu E, Iyo M. Critical role of brain-derived neurotrophic factor in mood disorders. Brain Research Reviews, 2004; 45: 104-14.

Herken H. Depresyon etyolojisinde genetik kanıtlar. Klinik psikiyatri. 2002; 4: 5-10.

Hoshaw BA, Malberg JE, Lucki I. Central administration of IGF-1 and BDNF leads to longlasting antidepressant-like effects. Brain Res, 2005; 1037: 204-8.

Kalueff AV, Wheaton M, Ren-Patterson R, Murphy DL. Brain-derived neurotrophic factor, serotonin transporter, and depression: comment on Kaufman et al. Biological psychiatry, 2007; 61: 1112-1113.

Katoh-Semba R, Wakako R, Komari T et al. Agerelated changes in BDNF levels in human serum: differences between autism cases and normal control. Int J Dev Neuroscience, 2007; 25: 36772. 
Kaufman J, Yang BZ, Douglas-Palumberi H, Grasso D, Lipschitz D, Houshyar S et al. Brain-derived neurotrophic factor-5-HTTLPR gene interactions and environmental modifiers of depression in children. Biol Psychiatry, 2006; 59: 673-80.

Lee BH, Kim H, Park SH, Kim YK. Decreased plasma BDNF levels in depressive patients. J Affect Disord, 2007;101: 239-44.

Mattson MP, Maudsley S, Martin B. A neural signaling triumvirate that influences ageing and age-related disease: insulin/IGF-I, BDNF and serotonin. Ageing Rresearch Reviews, 2004; 3: 445-64.

McCusker RH, McCrea K, Zunich S, Dantzer R, Broussard SR, Johnson RW et al. Insuline-like growth factor-I enhances the biological activity of brain-derived neurotrophic factor on cerebrocortical neurons. J Neuroimmunol, 2006: 179: 186-90.

O'Connor JC, McCusker RH, Strle K, Johnson RW, Dantzer R, Kelley KW. Regulating IGF-I function by proinflammatory cytokines: At th einterface of immunology and endocrinology. Cellular Immunology, 2008; 252: 91-110.

Öner N, Le Compte A (ed). Süreksiz durumluluk/ sürekli kayg1 envanteri el kitabı. İkinci bask1. İstanbul: Boğaziçi Üniversitesi Yayınları, 1985; $1-26$.

Öy B. Çocukluk Depresyonu Derecelendirme Ölçeği: Sağlıklı ve Çocuk Ruh Sağlı̆ğ Kliniğine Başvuran Çocuklarda Uygulanması. Türk Psikiyatri Dergisi, 1991; 2: 137-40.

Park RJ, Goodyer IM. Clinical guidelines for depressive disorders in childhood and adolescence. Eur Child Adolesc Psychiatry, 2000; 9: 147-61.

Schmidt HD, Duman RS. The role of neurotrophic factors in adult hippocampal neurogenesis, antidepressant treatments and animal models of depressive-like behavior. Behav Pharmacol, 2007; 18: 391-418.

Tapia-Arancibia L, Rage F, Givalois L andAracibia S. Physiology of BDNF: focus on hypothalamic function. Front in Neuroendocrinol, 2004; 25: 77107.

Uzbay İT. Nöroplastisite ve Depresyon. 1. bask1. Ankara: Çizgi Tıp yayınevi, 2005.

Wichers M, Kenis G, Jacobs $\mathrm{N}$ et al. The BDNF Val66MetX5-HTTLPRX Child adversity interaction and depressive symptoms: An attempt at replication. American Journal of Medical Genetics Part B (Neuropsychiatric Genetics), 2008; 147: 120-123. 